\title{
Evaluation of the relationship between gingival phenotype and alveolar bone morphology
}

\section{Diş eti fenotipi ve alveolar kemik morfolojisi arasındaki ilişkinin değerlendirilmesi}

\author{
Elif Bilgin ${ }^{1}$, Esra Ercan², Saliha Koprucu ${ }^{1}$, Saadettin Kayipmaz ${ }^{3}$
}

${ }^{1}$ Trabzon Oral and Dental Center, Trabzon, Turkey, ${ }^{2}$ Dept. of Periodontology, Canakkale Onsekiz Mart University, Faculty of Dentistry, Canakkale, Turkey, ${ }^{3}$ Dept. of Oral and Maxillofacial Radiology, Karadeniz Technical University, Faculty of Dentistry, Trabzon, Turkey

\begin{abstract}
Objective In recent years, the determination of gingival phenotype has gained importance in the field of dentistry. Bone and gingival relationship may directly affect the success rate of treatment modalities. The aim of this study is to evaluate the relationship between gingival phenotype and underlying alveolar bone thickness.

Methods In this study, we investigated the relationship between the clinical periodontal parameters and gingival phenotypes on the cone beam computed tomography (CBCT) image taken in the last 3 months of a total of 207 teeth. The gingival phenotype was identified as "thin" / "medium" / "thick" with the newly developed Hu-Friedy Colorvue ${ }^{\circledR}$ phenotype probe. Clinical periodontal parameters, width of keratinized tissue and gingival recession values were recorded. Buccal bone thickness was measured at three points, as crestal 1, 2 and $4 \mathrm{~mm}$. on CBCT images.

Results According to the results, in thin phenotype, width of keratinized gingiva and bone thickness at three levels was found significantly lower than thick phenotype ( $\mathrm{p}<0.016)$. In medium phenotype bone thickness at crestal 2 and $4 \mathrm{~mm}$ were found to be significantly less than the thick phenotype ( $\mathrm{p}<0.016)$. Additionally a negative correlation was seen between gingival recession and bone thickness at crestal 2 and $4 \mathrm{~mm}$ levels $(\mathrm{p}<0.05)$.

Conclusions We observed that there was a significant positive correlation between the gingival phenotype and buccal alveolar bone thickness. We suggest that the amount of bone thickness may be effective on ginigval recession.
\end{abstract}

Key words: gingiva; cone-beam computed tomography; alveolar bone

\section{O̊zet}

Amaç Son yıllarda diş hekimliği alanında, diş eti fenotipinin belirlenmesi oldukça önem kazanmıştır. Ayrıca kemik ve diş eti ilişkisi, pek çok tedavinin başarısını doğrudan etkilemektedir. Bu çalışmanın amacı, diş eti çekilmeleri, fenotipi ile destek alveoler kemik kalınlı̆̆ı arasındaki ilişkinin araştırılmasıdır.

Yöntem Bu çalışmada üst-alt kesici ve kanin olmak üzere toplam 207 dişe ait son 3 ayda çekilen konik 1şınlı bilgisayarlı tomografi görüntüsü üzerinde gerçekleştirilen radyolojik ölçümler ile klinik periodontal parametreler ve diş eti fenotiplerinin birbirleriyle ilişkileri incelendi. Diş eti fenotipi, yeni geliştirilmiş Hu-Friedy Colorvue® fenotip sondu ile "ince" / "orta" / "kalın" olarak belirlendi. Klinik periodontal parametreler, keratinize doku genişliği ve çekilme

Corresponding author: Esra Ercan, Dept. of Periodontology, Canakkale Onsekiz Mart University, Faculty of Dentistry, Canakkale, Turkey, Phone: +905469210382, E-mail: esraercan@comu.edu.tr

Received: 9 March 2019 Accepted: 25 March 2019

Conflicts of Interest: None

Funding: None 
derinliği değerleri kaydedildi. Bukkal kemik kalınlığı, konik ışınlı bilgisayarlı tomografi görüntüsü üzerinde, krestal 1, 2 ve 4 mm seviyelerinden olmak üzere üç noktadan ölçüldü.

Bulgular Gruplar arası karşılaştırma sonuçlarına göre, ince fenotipte keratinize doku genişliği ve üç seviyedeki kemik kalınlıkları kalın fenotipe göre istatistiksel olarak anlamlı derecede daha az bulundu $(\mathrm{p}<0.016)$. Orta fenotipte ise krestal 2 ve 4 mm'de kemik kalınlığı kalın fenotipe göre istatistiksel olarak anlamlı derecede daha az bulundu ( $\mathrm{p}<0.016)$. Ayrıca diş eti çekilmesi ile krestal 2 ve $4 \mathrm{~mm}$ seviyelerindeki kemik kalınlıkları arasında negatif korelasyon görüldü ( $\mathrm{p}<0.05)$.

Sonuçlar Bu çalışmanın sonucunda, diş eti fenotipi ile bukkal alveoler kemik kalınlığı arasında anlamlı pozitif korelasyon olduğu ve kemik kalınlığı miktarının diş eti çekilmesi üzerinde etkili olabileceği söylenebilir.

Anahtar kelimeler diş eti fenotipi; konik ışınlı bilgisayarlı tomografi; alveolar kemik

\section{Introduction}

Seibert and Lindhe ${ }^{1}$, who introduced the term "periodontal phenotype", classified the gingiva as "thick-flat" and "thin scalloped". The thick gingival phenotype is generally associated with large keratinized tissue and smooth gingival contour and is more resistant to inflammation or trauma. On the other hand, thin gingival phenotype is associated with a narrower keratinized tissue band and scalloped contour and is more susceptible to any inflammation or trauma. Inflammation of the periodontium causes periodontal pocket formation in thick phenotype and gingival recession in thin phenotype ${ }^{2}$. The definition of periodontal phenotypes and its relation to labial bone thickness are crucial at clinical treatments. Particularly in implantology, clinical evaluation of periodontal tissues is critical in achieving a successful outcome without complication. Additionally, identification and properties of periodontal phenotypes give valuable information to clinician before periodontal surgery, prosthetic treatments and orthodontic applications ${ }^{3}$. A thin phenotype is thought to be associated with a thin alveolar bone $e^{2,4}$. It was considered as a possible determinant in estimating the quality and quantity of bone $e^{5-7}$.
Visual inspection, direct measurement, probe transparency, ultrasonic device, parallel profile radiography and CBCT methods have been used to determine gingival thickness $^{8-12}$.

In our study, the gingival phenotype was determined by non-invasive, simple and reliable way with the newly developed Hu-Friedy Colorvue ${ }^{\circledR}$ phenotype probe and the relationship of gingival thickness with the alveolar bone was investigated. In this way, decision making for procedures like crest preservation, hard and soft tissue augmentation as well as protection of tissues prior to therapeutic procedures will be easier.

\section{Methods}

\section{Patient selection}

Twenty-five patients who admitted to the Department of Periodontology of the Faculty of Dentistry 01.04.201701.08.2017 were included in our study. Ethics committee approval was obtained from the local institutional review board (protocol no: 2017/69). The age of the patients ranged between 26 and 65 years, with a mean age of 43.3 years. Upper and lower incisor and canine teeth were included in our study. Clinical and radiographic measurements of 36 upper central, 36 upper lateral, 34 upper canine, 35 lower central, 35 lower lateral and 31 lower canine were recorded in the patients included in the study.

\section{Inclusion criteria}

The selection of individuals and teeth to be included in the study was made by considering the following criteria; Individual features:

- 18-65 years old,

- Has no systemic disease that may affect periodontal tissues,

- Do not use any medication that may affect periodontal tissues,

- No previous periodontal surgical treatment,

- Who have not previously received orthodontic treatment,

- Non-smoker,

- Patients who were willing to participate were included in the study. 
Tooth characteristics:

- There is no filling in the cervical area,

- No prosthetic restoration,

- No advanced periodontal destruction,

- Has no active periodontal disease,

- No gingival pigmentation,

- Periodontal pocket depth $<5 \mathrm{~mm}$,

- Teeth without fenestration and dehiscence were included in the study.

\section{Clinical index and measurements}

Patients who met the selection criteria were given detailed information about the clinical study and the study plan was explained. Informed consent form was signed. Age, gender, systemic status, oral hygiene habits and clinical measurements such as plaque index, gingival index, probing depth, bleeding index, keratinized gingival width (KGW), gingival recession depth (GR), occlusal trauma, wear and gingival phenotype were recorded in pre-prepared examination forms. During this process, $0.5 \mathrm{~mm}$ diameter Hu-Friedy periodontal probe was used. The newly developed Hu-Friedy Colorvue ${ }^{\circledR}$ phenotype probe was used to determine the gingival phenotype based on the transperancy of the probe (Fig 1). Measurements were made at mid-buccal of tooth from a single point by placing the probe in the gingival sulcus. The phenotype has three different colored resin tips (white, green, blue), allowing the gingival thickness to be classified as thin, medium and thick.

\section{Classification of gingival phenotype}

1. First, the white tip is placed at the gingiva at a pressure of $<30$ grams. If the color is visible through the gingival sulcus, the phenotype is categorized as "thin".

2. If the white color is not visible through the gingiva, the green tipped end is used in the same way. The phenotype is "middle" if the color is visible.

3. If the green color is not visible through the gingiva, the blue tip is used in the same way. If the color is visible, the phenotype is approved as "thick".

\section{Radiological measurements}

The patients to be included in the study were selected among the individuals who had taken the CBCT be-

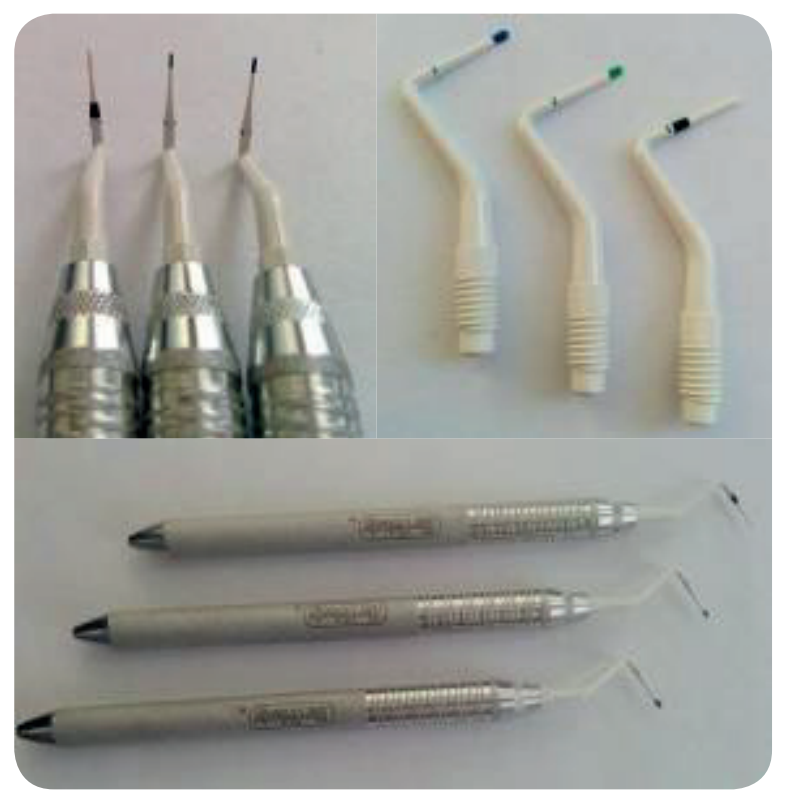

Fig. 1. Hu-Friedy Colorvue ${ }^{\circledR}$ phenotype probe

cause of any necessity in the Department of Oral, Dental and of the Faculty of Dentistry of Karadeniz Technical University. For the CBCT, the Kodak 9500 Cone Beam 3D System ${ }^{\circledR}$ (Carestream Health, Rochester NY, USA) with $2001 \mathrm{~m}$ voxel was used. The imaging area of the tomography device is $9 \times 15 \mathrm{~cm}$ and the shooting time is $10.8 \mathrm{sec}$. The tube voltage of the device was $90 \mathrm{kV}$, the tube current was $10 \mathrm{~mA}$, the focal spot was $0.7 \times 0.7$ $\mathrm{mm}$ and the gray scale was 14 bits. Radiological measurements include measurements of rotation, angulation, distance between the cemento-enamel junction and the alveolar crest and buccal bone thickness measurements. All measurements were performed by the same clinician at two separate times.

* Rotation: Rotations of teeth in their alveolar sockets were recorded.

* Angulation: The angle between the axis of the fascia of the bone at the apex line of the teeth and the axis joining the cutting edge and the long axis of the tooth was measured. In the lower teeth, the angle between the long axis of the mandible and the long axis of the tooth was measured.

* Cemento-Enamel Junction - Alveolar Crest Distance (CEJ-AC): The CEJ-AC distance was measured with 
$0.1 \mathrm{~mm}$ accuracy at the mid-buccal point on the CBCT cross-section of all the teeth included in the study.

* Buccal Bone Thickness (BT): BT measurements were recorded on the mid-buccal CBCT cross section taken perpendicular to the tooth axis with a precision of $0.1 \mathrm{~mm}$. BTs were measured at three points, $1 \mathrm{~mm}$ (BT1), $2 \mathrm{~mm}$ (BT2) and $4 \mathrm{~mm}$ (BT4) apical in the alveolar crest (Fig. 2).

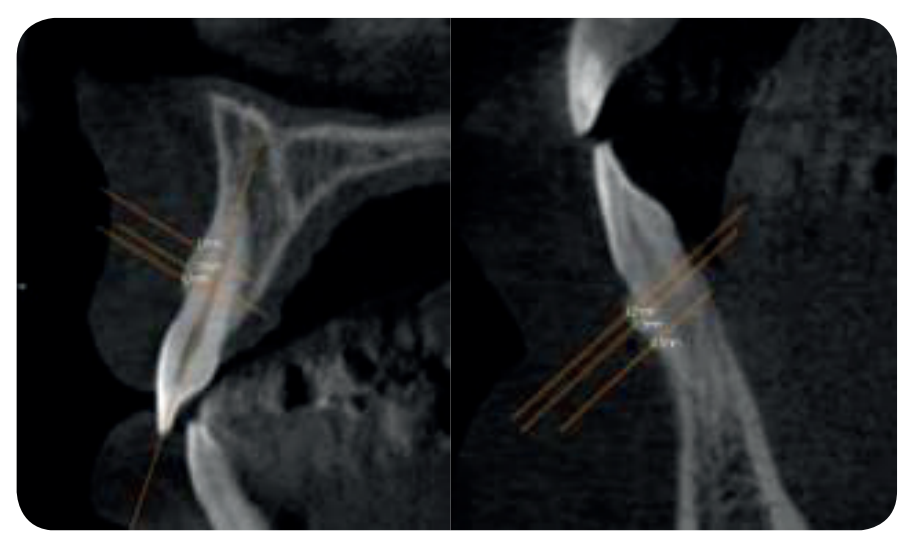

Fig. 2. Measurement of buccal bone thickness at three points on the upper and lower teeth

\section{Statistical analysis}

In our study, descriptive statistics of clinical and radiographic data were made according to tooth types and gingival phenotypes. Kruskal-Wallis test was used to analyze the relationship among the three gingival phenotypes and clinical and radiographic findings. $\mathrm{P}<0.05$ was considered statistically significant. Bonferroni-corrected Mann-Whitney U Test was applied as a post-hoc test for those with significant differences between the three groups. In this test, the comparison of the differences was made by pairwise comparisons and the $p$ value $<0.016$ was considered statistically significant. Spearman correlation test was applied for data analysis among gingival recession, KGW and radiographic findings. Correlation analysis between the angle and the phenotype was performed separately in the upper and lower jaw. Kruskal-Wallis test was applied for upper jaw datas because they did not show normal distribution, and ANOVA test was applied since the lower jaw data showed normal distribution. $\mathrm{P}<0.05$ was considered statistically significant.

\section{Results}

Ninety-five of 207 teeth were found to be thin (45.9\%), 40 were medium (19.3\%) and 72 were thick phenotype (34.8\%).

The phenotype distributions according to the tooth types are as follows:

- Upper central tooth ( $\mathrm{n}=36)$ : $22 \%$ thin, $20 \%$ medium, 58\% thick,

- Upper lateral tooth ( $\mathrm{n}=36)$ : $47 \%$ thin, $14 \%$ medium, 39\% thick,

- Upper canine teeth ( $\mathrm{n}=34): 56 \%$ thin, 9\% medium, 35\% thick,

- Lower central tooth ( $\mathrm{n}=35)$ : $49 \%$ thin, 34\% medium, $17 \%$ thick,

- Lower lateral tooth ( $\mathrm{n}=35)$ : $43 \%$ thin, $20 \%$ medium, 37\% thick,

- Lower canine teeth ( $n=31$ ) 61\% thin, 19\% medium, 20\% thick phenotype.

The rate of thin phenotype was the highest in the lower canine teeth (61\%), and the least in the upper central tooth $(22 \%)$. Thick phenotype ratio was highest in upper central teeth (58\%) and lower in central teeth (17\%). The difference between phenotype distributions was statistically significant $(\mathrm{p}<0.05)$.

When the upper and lower jaw were evaluated separately; a hundred and six teeth measured in the upper jaw, 44 were thin (41.5\%), 15 were medium (14.2\%) and 47 were thick (44.3\%). A hundred and one teeth measured in the lower jaw, 51 were thin (50.5\%), 25 were medium (24.8\%) and 25 were thick (24.8\%). Phenotype differences in the lower and upper jaw were statistically significant $(\mathrm{p}<0.05)$.

When the brushing habits of the patients were evaluated, it was recorded that $30.4 \%$ of the patients brushed their teeth once a day, $69.6 \%$ brushed their teeth 2 or 3 times a day. The brush types used are; $30.4 \%$ were soft, $17.4 \%$ were hard and $52.2 \%$ were medium hardness.

A significant difference was found among the three gingival phenotypes in terms of KGW, BT1, BT2 and BT4. The angle measurement was performed separately in the lower and upper jaw. The results of intergroup analysis 
Table 1. Comparision of parameters among phenotype groups

\begin{tabular}{|c|c|c|c|c|}
\hline & Thin phenotype & Medium phenotype & Thick phenotype & $P$ \\
\hline KGW & $5.17 \pm 1.68^{\mathrm{a}}$ & $5.50 \pm 1.91$ & $6.25 \pm 1.77^{\mathrm{a}}$ & 0.000 \\
\hline $\mathrm{RD}$ & $0.44 \pm 0.79$ & $0.42 \pm 0.75$ & $0.26 \pm 0.58$ & NS \\
\hline Rotation & $0.82 \pm 3.49$ & $1.07 \pm 10.13$ & $0.60 \pm 2.37$ & NS \\
\hline Angulation (Upper) & $12.98 \pm 30.08$ & $32.93 \pm 58.63$ & $12.85 \pm 31.59$ & NS \\
\hline Angulation (Lower) & $153.10 \pm 9.32$ & $156.80 \pm 7.67$ & $156.08 \pm 6.07$ & NS \\
\hline CEJ-AC & $2.48 \pm 1.05$ & $2.74 \pm 1.06$ & $2.82 \pm 1.20$ & NS \\
\hline BT1 & $0.92 \pm 0.31^{\mathrm{a}}$ & $0.91 \pm 0.39$ & $1.04 \pm 0.29^{\mathrm{a}}$ & 0.005 \\
\hline BT2 & $0.98 \pm 0.40^{\mathrm{a}}$ & $0.92 \pm 0.53^{b}$ & $1.18 \pm 0.40^{\mathrm{a}, \mathrm{b}}$ & 0.001 \\
\hline BT4 & $0.85 \pm 0.45^{\mathrm{a}}$ & $0.82 \pm 0.64^{b}$ & $1.10 \pm 0.61^{\mathrm{a}, \mathrm{b}}$ & 0.002 \\
\hline
\end{tabular}

( $<<0.016$ statistically significant. KGW, Keratinized Gingival Width ; RD, Recession Depth ; BT 1, Buccal Bone Thickness at Crestal 1 mm ; BT 2, Buccal Bone Thickness at Crestal $2 \mathrm{~mm}$; BT 4, Buccal Bone Thickness at Crestal $4 \mathrm{~mm}$; NS, Statistically non-significant)

are shown in Table 1. Keratinized gingival width is significantly lower in the thin gingival phenotype group $(5.17 \pm 1.68 \mathrm{~mm})$ than in the thick gingival phenotype group $(6.25 \pm 1.77 \mathrm{~mm})(\mathrm{p}<0.05)$. The thickness of bone at BT1 was significantly lower in teeth with thin phenotypes than those with thick phenotypes $(\mathrm{p}<0.05)$. Bone thicknesses at BT2 and BT4 were also significantly lower in the thin and medium phenotyped teeth than in the thick phenotyped teeth $(\mathrm{p}<0.05)$.

Correlation analysis was performed among gingival recession, KGW and radiographic data.

According to the results of the analysis;

* There is a positive correlation between ile GR and CEJ-AC distance at 0.01 level. Accordingly, as the RD increases, the CEJ-AC distance increases.

* There is a negative correlation between RD and BT2 at 0.05 level and between BT4 at 0.01 level. Accordingly, as the RD increases, bone thickness values decrease at the levels of BT2 and BT4.

* There is a positive correlation between KGW and BT1, BT2 and BT4 at 0.01 level. Accordingly, as the KGW increases, the BT1, BT2 and BT4 values also increases.

\section{Discussion}

It is important for an oral clinician to define the periodontal phenotype, because the anatomical characteristics of the periodontium, such as gingival thickness, gingival width and alveolar bone morphology, determine the behavior of the periodontium against physical, chemical or bacterial damage during therapeutic procedures or periodontal surgery, implant treatment, and orthodontic treatment ${ }^{13-15}$. The gingival thickness is supposed to play an imoportant role in the development of mucogingival problems, wound healing and gingival recession treatment. The thick gingival phenotype provides additional blood support during wound healing, since there is no periodontal ligament support in implant therapies ${ }^{17}$. In patients with thin phenotypes, it is beneficial to increase the soft tissue to preserve and regenerate adequate papilla height when immediate implant is planned in areas with high aesthetic expectation ${ }^{18}$. 
Generally, simple visual examination is used to determine gingival thickness. Although there is no certainty of this method, the phenotype was correctly detected in only half of the cases, regardless of the clinician's experience ${ }^{19}$.

Therefore, different methods such as probe transparency, direct measurement, ultrasound device and CBCT were used to give accurate information ${ }^{8-12}$. In our study, considering the difficulties and disadvantages of the measurement methods, the recently developed $\mathrm{Hu}-$ Friedy Colorvue ${ }^{\circledR}$ phenotype was used to determine the gingival phenotype. This phenotype probe is a simple, inexpensive, practical and non-invasive method which allows the classification of gingival thickness as thin, medium and thick. In our study, only anterior teeth were evaluated since the aesthetic concerns about tooth and implant treatment are mostly experienced in the anterior region.

In our study, CBCT was used for bone thickness measurement and other radiographic evaluations. In a study conducted by $\mathrm{Fu}$ et al. ${ }^{4}$ clinical and CBCT measurements of alveolar bone thicknesses measured on cadavers showed consistent results and no statistically significant difference was observed between them.

In studies investigating the effects of variables on the anatomy of the jawbone, the phenotype was considered to be a possible determinant in predicting the quality and quantity of the underlying bone $e^{5-7}$. In our study, a significant positive correlation was found between gingival phenotype and bone thickness measurements. Cook et al. ${ }^{6}$ reported that thinner gingival phenotype was associated with decreased bone thickness. Kheur et al. ${ }^{20}$ investigated the relationship between bone thickness and soft tissue in the labial and palatal of the maxillary central teeth. As a result of their study, there was a positive correlation between labial and palatal bone and related soft tissue thicknesses.

In contrary to these findings, Maynard and Wilson ${ }^{21}$ have stated that there is no correlation between hard Wand soft tissue thicknesses. Similarly, La Rocca et al. ${ }^{22}$ showed that there is not a statistically significant correlation between gingival thickness and bone thickness measurements at the maxillary and mandibular anterior region. In this study, gingival thickness was determined by transgingival measurement method. This method may increase the gingival volume due to the infusion of the anesthetic fluid and thus creates a suspicion for the reliability of the results ${ }^{23}$.

In our study, whether there is a phenotype difference between the upper and lower jaw is also evaluated. According to the results, thick phenotype ratio in the maxilla was higher than the lower jaw and this difference was statistically significant $(\mathrm{p}<0.05)$. The results of our study are similar to those of Müller ${ }^{24}$ and Cuny-Houchmand $^{25}$ who found higher gingival thickness at upper jaw than lower jaw.

In our study, one of the main issues we investigated was the relationship of gingival recession with phenotype and alveolar bone. Although it is expected that gingival recession will be associated with a thin phenotype, no significant difference was found between the phenotypes and GR. Although GR measurements yield similar results in thin and medium phenotypes, they tend to be higher in thick phenotypes. On the other hand, Shah et al. ${ }^{26}$ demonstrated a relationship between gingival thickness and the presence of GR. Another frequently encountered mucogingival problem is keratinized tissue deficiency. In our study, according to the comparison of groups in terms of $\mathrm{KGW}$, a narrower $\mathrm{KGW}$ was measured in thin phenotype group than thick phenotype group and the the difference between the groups was statistically significant. These results are consistent with the results of the study by Olsson et al. ${ }^{28}$, in which they found a strong association between gingival thickness and KGW. Likewise, Cook et $\mathrm{a}^{16}$. suggested that thin phenotypes have been associated with a narrower keratinised gingival tissue.

\section{Conclusion}

We suggest that $\mathrm{Hu}$-Friedy Colorvue ${ }^{\circledR}$ phenotype probe was an effective, safe and practical method in determining the phenotype, and there was a significant correlation between the determined phenotype and buccal bone thickness. However, more studies are needed to 
determine how the phenotype determined by the probe actually corresponds to the number of millimeters of gums.

\section{References}

1. Seibert J, Lindhe J. Textbook of clinical periodontology. Copenhangen, Denmark: Munksgaard International Publishers; 1989.

2. Kao RT, Fagan MC, Conte GJ. Thick vs. thin gingival phenotypes: a key determinant in treatment planning for dental implants. J Calif Dent Assoc 2008;36:193-8.

3. Nikiforidou M, Tsalikis L, Angelopoulos C, et al. Classification of periodontal phenotypes with the use of CBCT. A cross-sectional study. Clin Oral Investig 2016;20:2061-71.

4. Fu JH, Yeh CY, Chan HL, et al. Tissue phenotype and its relation to the underlying bone morphology. Journal of periodontology 2010;81:569-74.

5. Verdugo F, Simonian K, Nowzari H. Periodontal phenotype influence on the volume maintenance of onlay grafts. J Periodontol 2009;80:816-23.

6. Cook DR, Mealey BL, Verrett RG, et al. Relationship between clinical periodontal phenotype and labial plate thickness: an in vivo study. Int J Periodontics Restorative Dent 2011;31:345-54.

7. Zuiderveld EG, den Hartog L, Vissink A, Raghoebar GM, Meijer HJ. Significance of buccopalatal implant position, phenotype, platform switching, and pre-implant bone augmentation on the level of the midbuccal mucosa. Int J Prosthodont 2014;27:477-9.

8. Alpiste-Illueca F. Dimensions of the dentogingival unit in maxillary anterior teeth: a new exploration technique (parallel profile radiograph). Int J Periodontics Restorative Dent 2004;24:386-96.

9. Barriviera M, Duarte WR, Januario AL, Faber J, Bezerra AC. A new method to assess and measure palatal masticatory mucosa by cone-beam computerized tomography. J Clin Periodontol 2009;36:564-8.

10. Kan JY, Rungcharassaeng K, Umezu K, Kois JC. Dimensions of peri-implant mucosa: an evaluation of maxillary anterior single implants in humans. J Periodontol 2003;74:557-62.

11. Muller HP, Schaller N, Eger T, Heinecke A. Thickness of masticatory mucosa. J Clin Periodontol 2000;27:431-6.

12. Kloukos D, Koukos G, Doulis I, et al. Gingival thickness assessment at the mandibular incisors with four methods. A cross-sectional study. J Periodontol 2018;89:1300-9.

13. Zigdon H, Machtei EE. The dimensions of kerati- nized mucosa around implants affect clinical and immunological parameters. Clin Oral Implants Res 2008;19:387-92.

14. Unal G, Aksakalli, S. Ortodontik Tedavi ve Diseti. Ataturk Universitesi Dis Hekimligi Fakultesi Dergisi 2015;25.

15. De Rouck T, Eghbali R, Collys K, De Bruyn H, Cosyn $\mathrm{J}$. The gingival phenotype revisited: transparency of the periodontal probe through the gingival margin as a method to discriminate thin from thick gingiva. J Clin Periodontol 2009;36:428-33.

16. Malhotra R, Grover V, Bhardwaj A, Mohindra K. Analysis of the gingival phenotype based on the measurement of the dentopapillary complex. J Indian Soc Periodontol 2014;18:43-7.

17. Evans CD, Chen ST. Esthetic outcomes of immediate implant placements. Clin Oral Implants Res 2008;19:73-80.

18. Gastaldo JF, Cury PR, Sendyk WR. Effect of the vertical and horizontal distances between adjacent implants and between a tooth and an implant on the incidence of interproximal papilla. J Periodontol 2004;75:1242-6.

19. Eghbali A, De Rouck T, De Bruyn H, Cosyn J. The gingival phenotype assessed by experienced and inexperienced clinicians. J Clin Periodontol 2009;36:958-63.

20. Kheur MG, Kantharia NR, Kheur SM, et al. Three-dimensional evaluation of alveolar bone and soft tissue dimensions of maxillary central incisors for immediate implant placement: a cone-beam computed tomography assisted analysis. Implant Dent 2015;24:407-15.

21. Maynard JG, Jr, Wilson RD. Diagnosis and management of mucogingival problems in children. Dent Clin North Am 1980;24:683-703.

22. La Rocca AP, Alemany AS, Levi P, et al. Anterior maxillary and mandibular phenotype: relationship between gingival thickness and width with respect to underlying bone thickness. Implant Dent 2012;21:507-15.

23. Ronay V, Sahrmann P, Bindl A, Attin T, Schmidlin PR. Current status and perspectives of mucogingival soft tissue measurement methods. J Esthet Restor Dent 2011;23:146-56.

24. Cuny-Houchmand M, Renaudin S, Leroul M, et al. Gingival phenotype assessement: visual inspection relevance and maxillary versus mandibular comparison. Open Dent J 2013;7:1-6.

25. Muller HP, Heinecke A, Schaller N, Eger T. Masticatory mucosa in subjects with different periodontal phenotypes. J Clin Periodontol 2000;27:621-6.

26. Shah R, Sowmya NK, Mehta DS. Prevalence of gingival phenotype and its relationship to clinical parame- 
ters. Contemp Clin Dent 2015;6:167-71.

27. Nizam N, Akcali, A. Microsurgery in the treatment of gingival recessions: A review of the literature. J Dent Fac Ataturk University 2014;24:283-90.

28. Olsson M, Lindhe J, Marinello CP. On the relationship between crown form and clinical features of the gingiva in adolescents. J Clin Periodontol 1993;20:570-7. 